\title{
GROUNDWATER QUALITY AND ITS SUITABILITY FOR DOMESTIC AND AGRICULTURAL USES IN WILBERFORCE ISLAND, SOUTHERN NIGERIA
}

KENNETH S. OKIONGBO AND ELIJAH I. OHIMAIN

(Received 13 January 2013; Revision Accepted 3 March 2014)

\begin{abstract}
Hydrogeochemical analysis of groundwater samples collected from parts of the Wilberforce Island in Bayelsa State, Southern Nigeria has been carried out in an attempt to assess the suitability of the groundwater for domestic and agricultural purposes in the area. The study was based on thirteen groundwater samples collected from domestic boreholes analysed for some physical and chemical constituents including electrical conductance, $\mathrm{pH}$, total dissolved solids (TDS), alkalinity, hardness, $\mathrm{Na}^{+}, \mathrm{K}^{+}, \mathrm{Ca}^{2+}, \mathrm{Mg}^{2+}, \mathrm{Fe}, \mathrm{Cl}^{-}, \mathrm{SO}_{4}^{2-}, \mathrm{NO}_{3}^{-}$, and $\mathrm{HCO}_{3}$. The quality of the groundwater samples was evaluated with reference to WHO standards. The results obtained showed that the concentration of dissolved major cations and anions in the groundwater vary spatially and mass abundance was in the order of: $\mathrm{Ca}^{2+}>$ $\mathrm{Na}^{+}>\mathrm{Fe}>\mathrm{K}^{+}>\mathrm{Mg}^{2+}$ for cations and $\mathrm{Cl}^{-}>\mathrm{HCO}_{3}{ }^{-}>\mathrm{CO}_{3}{ }^{-}>\mathrm{NO}_{3}{ }^{-}>\mathrm{SO}_{4}{ }^{2-}$ for anions. The concentration of these ions as well as such parameters as total hardness and TDS are below the World Health Organisation (WHO) standard for domestic uses of water in over $80 \%$ of the samples. However, iron was over $3000 \%$ higher than the WHO permissible limits. The groundwater in the area is fresh, high salinity and low sodium in nature. $\mathrm{Ca}-\mathrm{HCO}_{3}$ and $\mathrm{Ca}-\mathrm{Cl}-\mathrm{HCO}_{3}$ are the dominant hydrochemical facies of the study area. Alkali earths metals $\left(\mathrm{Ca}^{2+}\right.$ and $\left.\mathrm{Mg}^{2+}\right)$ and strong acids $\left(\mathrm{Cl}^{-}\right.$ and $\left.\mathrm{SO}_{4}{ }^{2-}\right)$ are slightly dominating over the alkali metals $\left(\mathrm{Na}^{+}\right.$and $\left.\mathrm{K}^{+}\right)$and weak acid anions $\left(\mathrm{HCO}_{3}^{-}\right.$and $\left.\mathrm{CO}_{3}{ }^{2-}\right)$.
\end{abstract}

KEYWORDS: Groundwater quality, hydrogeochemical, sodium percent, sodium adsorption ratio, Wilberforce Island

\section{INTRODUCTION}

The Wilberforce Island in Bayelsa state is the host of the prestigious state owned Niger Delta University, and thus a fast growing urban centre. The Island lacks municipal water supply, therefore, groundwater is the major and preferred source of drinking water for over $95 \%$ of the residents. This has placed a high demand on the groundwater resource on the Island.

Despite the importance of groundwater in the Wilberforce Island, there had been no detailed characterisation of the groundwater quality, and little is known about the natural phenomena that govern the chemical composition of groundwater or anthropogenic factors that presently affect them. Groundwater contains a wide variety of dissolved inorganic chemical constituents as a result of the hydrogeochemical processes that alter its chemical composition as it flows along its path from recharge to discharge areas. The suitability of groundwater for domestic use, industrial and irrigation purposes depends on its hydrogeochemical composition (Singh and Singh 2008), and that can be indicative of its origin and history of the passage through the underground materials with which the water has been in contact (Prasana et al. 2011). The hydrogeochemical composition of groundwater is controlled by many factors such as composition of precipitation, geological structure and mineralogy of the watersheds and aquifers (Andre et al. 2005). The interaction of all the factors leads to various water types of different qualities.

Characterisation of the physical and chemical components that determine the groundwater quality is of value because it helps to define the impacts of concentrated urban living on our environment. It is also useful in that it could provide baseline water quality data which could be used to evaluate the effect of further urbanization. Additionally, increased knowledge of geochemical evolution of groundwater in this shallow aquifer could lead to improved understanding of hydrochemical systems in the area; leading to sustainable development of water resources and effective management of groundwater resource for the Wilberforce Island. Prior to the present study, little was known about the chemical components of groundwater and major hydrochemical processes that control the observed water chemistry. The present study was conducted with an object to assess the current status of groundwater chemistry and water quality in the Wilberforce Island.

\section{Description of the Study Area}

The study area lies between longitudes $006^{\circ} 05^{\circ}$ and $006^{\circ} 025^{\prime}$ East of the prime meridian and latitudes $04^{\circ} 23.3^{\prime}$ and $04^{\circ} 38.2^{\prime}$ North of the equator within the coastal area of the recent Niger Delta (Fig. 1) and consists of seven communities including Amassoma,

Kenneth S. Okiongbo, Department of Geology \& Physics, Niger Delta University, Wilberforce Island, Bayelsa State, Nigeria

Elijah I. Ohimain, Department of Biological Sciences, Niger Delta University, Wilberforce Island, Bayelsa State, Nigeria 
Ikibiri, Igbedi, Agudama - Ekpetiama etc. The estimated population of the Island is over 300,000 people. It has an areal extent of about $100 \mathrm{~km}^{2}$ and is within the tropical equatorial climate region. The topography of the area is generally gentle and elevation of the Island is below $50 \mathrm{~m}$ above mean sea level $(\mathrm{msl})$. There are two major climatic seasons in the area, the wet season from April to October and the dry season from November to March. Average annual rainfall there is about $3000 \mathrm{~mm}$ and this serves as the major source of groundwater recharge. There are a number of perennial streams and rivers in the area e.g. Sagbarea Creek, Amassoma River, etc. They all form a network which empties to the Atlantic Ocean through Nun River Estuary.

The low-lying alluvial plains are characterised by vegetation consisting of diverse kinds of evergreen trees and oil palms. In addition, there are smaller climbing plants, parasitic plants that live on other plants. More than $70 \%$ of the inhabitants of the study area are engaged in subsistent farming and fishing.

\section{Geology and Hydrogeology}

The study area (Fig.1), physiographically lies within the fresh water and meander belt geomorphic unit of the Niger Delta. The formation of the present Niger Delta started during Early Paleocene which resulted from the built - up of fine grained sediments eroded and transported by the River Niger and its tributaries. Specifically, the Wilberforce Island is underlain by the deposits of the modern and Holocene delta top deposits. The deposits of the Freshwater swamps are considered to be recent expressions of and a continuation of the Benin Formation (Durotoye 1989).

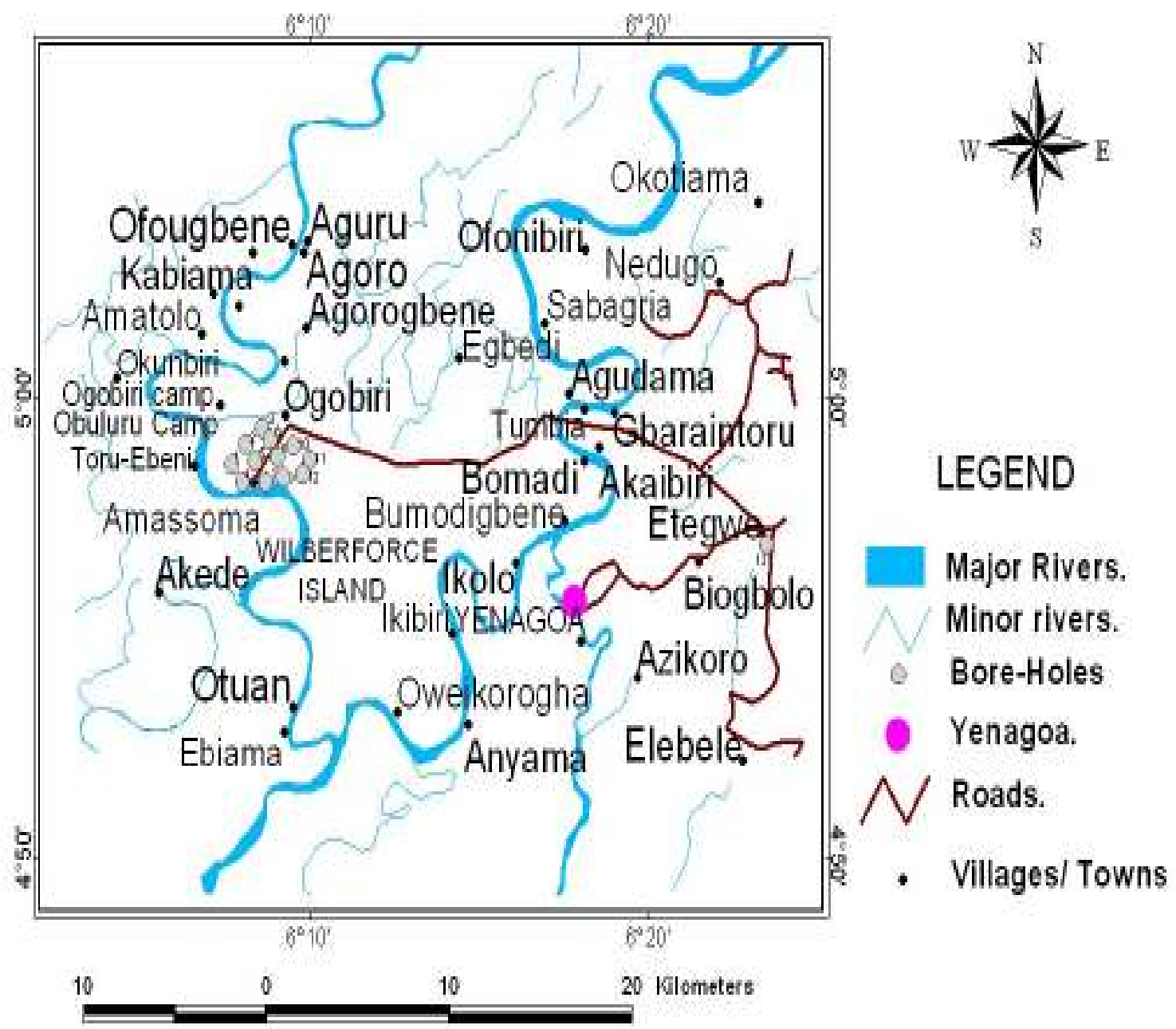

Fig. 1: Map of study area showing the Borehole locations

They result from the sediment laden discharges of the River Niger that is spread on the delta by its various tributaries. The sediment is generally an admixture of medium to coarse-grained sands, sandy clays, silts and clays that eventually settle in fluvial/tidal channel, tidal flat and mangrove swamp environments, a process that has been ongoing since the late Quaternary and is related to interglacial marine transgressions (Allen 1965; Oomkens 1974; Durotoye 1989).

The deposits constitute the shallow unconfined aquifer that is exploited by shallow $(<30 \mathrm{~m})$ boreholes and dug wells that serve as the primary water supply source for many semi-urban and urban communities in the area and in the Niger Delta region in general (Amajor 1991). The regional geology of the Niger Delta 
consists of three lithostratigraphic units, Akata, Agbada and Benin Formations, overlain by various types of Quaternary Deposits (Short and Stauble 1967; Wright et al. 1985; Kogbe 1989). These Quaternary Sediments, according to Osukani and Abam (2004), are largely alluvial and hydromorphic soils and lacustrine sediments of Pleistocene age. The Benin Formation, the youngest of the three important formations that constitute the sedimentary fill of the Niger Delta Basin is usually described as consisting of massive continental/fluvial sands and gravels and is considered as the major water bearing formation. The age of this Formation ranges from Miocene to Recent. Water table in large sections of the Niger Delta is close to the surface but subject to spatial and seasonal variations. In the study area, the water table is about $3-4 \mathrm{~m}$ during the dry season. During the wet season, the water table rises considerably, in some cases, to the ground surface. The older and underlying Agbada Formation consists of paralic sands and shales. The basal Akata Formation of Eocene to Recent age (Amadi et al. 1987) consists of marine shales, silts and clays.

\section{METHOD OF STUDY}

Water samples were collected from 13 wells distributed over the study area during the month of February, 2013 (Table 1). Water samples were collected in clean polyethylene bottles. All sampling bottles were soaked with 1:1 $\mathrm{HNO}_{3}$ and washed using detergent. These bottles were then rinsed $2-3$ times using the groundwater to be sampled. Samples were collected after pumping the water for about 10 minutes. Electrical Conductivity (EC) and $\mathrm{pH}$ of groundwater samples were measured in the field immediately after sample collection using portable field kits (Hach's CO 150 Conductivity/TDS meter and $\mathrm{pH}$ meter respectively).

Table 1: Sample locations in Wilberforce Island

\begin{tabular}{|c|c|c|c|}
\hline $\mathrm{S} / \mathrm{N}$ & Sample Location & Location Coordinates & Sample Code \\
\hline 1 & AMASSOMA - 1 & $\begin{array}{l}\text { N04 }^{0} 58.237^{1} \\
\text { E006 }^{0} 06.915^{1}\end{array}$ & $\mathrm{BH} 1$ \\
\hline 2 & AMASSOMA -2 & $\begin{array}{l}\text { N04 }^{0} 58.381^{1} \\
\text { E006 } \\
0\end{array}$ & $\mathrm{BH} 2$ \\
\hline 3 & AMASSOMA -3 & $\begin{array}{l}\text { N04 }^{0} 58.459^{1} \\
\text { E006 }^{0} 06.518^{1}\end{array}$ & $\mathrm{BH} 3$ \\
\hline 4 & AMASSOMA -4 & $\begin{array}{l}\text { N04 }^{0} 58.330^{1} \\
\text { E006 }^{0} 06.835^{1}\end{array}$ & $\mathrm{BH} 4$ \\
\hline 5 & AMASSOMA -5 & $\begin{array}{l}\text { N04 }^{0} 58.199^{1} \\
\text { E006 }^{0} 06.373^{1}\end{array}$ & $\mathrm{BH} 5$ \\
\hline 6 & AMASSOMA - 6 & $\begin{array}{l}\text { N04 }^{0} 58.308^{1} \\
\text { E006 }^{0} 06.716^{1}\end{array}$ & $\mathrm{BH} 6$ \\
\hline 7 & AMASSOMA -7 & $\begin{array}{l}\text { N04 }^{0} 58.372^{1} \\
\text { E006 }^{0} 06.716^{1}\end{array}$ & $\mathrm{BH} 7$ \\
\hline 8 & AMASSOMA -8 & $\begin{array}{l}\text { N04 }^{0} 58.218^{1} \\
\text { E006 }^{0} 06.246^{1}\end{array}$ & $\mathrm{BH} 8$ \\
\hline 9 & B1 & $\begin{array}{l}\text { N04 }^{0} 58.195^{1} \\
\text { E006 }^{0} 05.378^{1}\end{array}$ & $\mathrm{BH} 9$ \\
\hline 10 & B2 & $\begin{array}{l}\text { N04 }^{0} 58.192^{1} \\
\text { E006 }^{0} 05.295^{1}\end{array}$ & $\mathrm{BH} 10$ \\
\hline 11 & B3 & $\begin{array}{l}\text { N04 }^{0} 58.231^{1} \\
\text { E006 }^{0} 05.280^{1}\end{array}$ & $\mathrm{BH} 11$ \\
\hline 12 & $\mathrm{CHS}$ & $\begin{array}{l}\text { N04 }^{0} 58.138^{1} \\
\text { E} 006^{0} 05.700^{1}\end{array}$ & $\mathrm{BH} 12$ \\
\hline 13 & NIT & $\begin{array}{l}\mathrm{N}^{0} 4^{0} 56.688^{1} \\
\text { E006 }^{0} 21.123^{1}\end{array}$ & $\mathrm{BH} 13$ \\
\hline
\end{tabular}

The samples were analysed for major cations $\left(\mathrm{Na}^{+}, \mathrm{Ca}^{2+}, \mathrm{Mg}^{2+}, \mathrm{K}^{+}\right)$and anions $\left(\mathrm{Cl}^{-}, \mathrm{SO}_{4}{ }^{2-}, \mathrm{CO}_{3}{ }^{2-}\right.$, $\left.\mathrm{HCO}_{3}{ }^{-}\right)$. The chemical analysis was carried out using the standard methods as suggested by the American Public Health Association (APHA 1998). Sulphate $\left(\mathrm{SO}_{4}{ }^{2-}\right)$ concentration in the groundwater samples was analysed using the turbidimetric method. The method is based on the principle of formation of barium sulphate in the presence of (acidified $\mathrm{HCl}$ ) barium chloride. The process is enhanced in the presence of glycerol or other organic compound. The absorbance of the colloidal solution was measured against a standard on UV visible Spectrophotometer. Sodium $\left(\mathrm{Na}^{+}\right)$and potassium $\left(\mathrm{K}^{+}\right)$ content was determined by flame-emission method using a flame photometer while calcium $\left(\mathrm{Ca}^{2+}\right)$, magnesium $\left(\mathrm{Mg}^{2+}\right)$, chloride $\left(\mathrm{Cl}^{-}\right)$, carbonate $\left(\mathrm{CO}_{3}{ }^{2-}\right)$ and bicarbonate $\left(\mathrm{HCO}_{3}^{-}\right)$were determined by titration. The analytical data quality was evaluated by computing the charge balance error (CBE), which is calculated by comparing the sum of the equivalents of the cations with 
the sum of equivalents of the anions (Hounslow 1995). A positive result means that either an excess cation or insufficient anion exists, while a negative result means the opposite. The analytical precision for the measurement of ions was determined by calculating the ionic balance error, which is generally within $10 \%$. Statistical analysis was carried out using SPSS version 17 (SPSS Inc, Chicago, III)

\section{RESULTS AND DISCUSSION}

Table 2 displays the results of the hydrogeochemical analysis of the groundwater samples, and Table 3 gives the descriptive statistical measures such as minimum, maximum, mean and standard deviation values of various investigated parameters along with the World
Health Organisation (WHO) standards (WHO 2004). Assessment of the groundwater suitability for domestic uses and domestic consumption was evaluated by comparing the hydrochemical parameters of the groundwater in the study area with the prescribed specification of World Health Organisation (WHO 2004). The concentrations of dissolved major cations and anions in the groundwater vary spatially. The abundance of the major ions in the groundwater is in the following order: $\mathrm{Ca}^{2+}>\mathrm{Na}^{+}>\mathrm{K}^{+}>\mathrm{Fe}>\mathrm{Mg}^{2+}$ and $\mathrm{Cl}^{-}>$ $\mathrm{HCO}_{3}^{-}>\mathrm{CO}_{3}^{-}>\mathrm{NO}_{3}^{-}>\mathrm{SO}_{4}^{2-}$ respectively. The $\mathrm{pH}$ values of the samples ranged from $5.8-6.8$ with a mean of 6.4 which is below the stipulated $\mathrm{WHO} \mathrm{pH}$ tolerance range of $6.5-8.6$ for potable water (WHO 2004). 


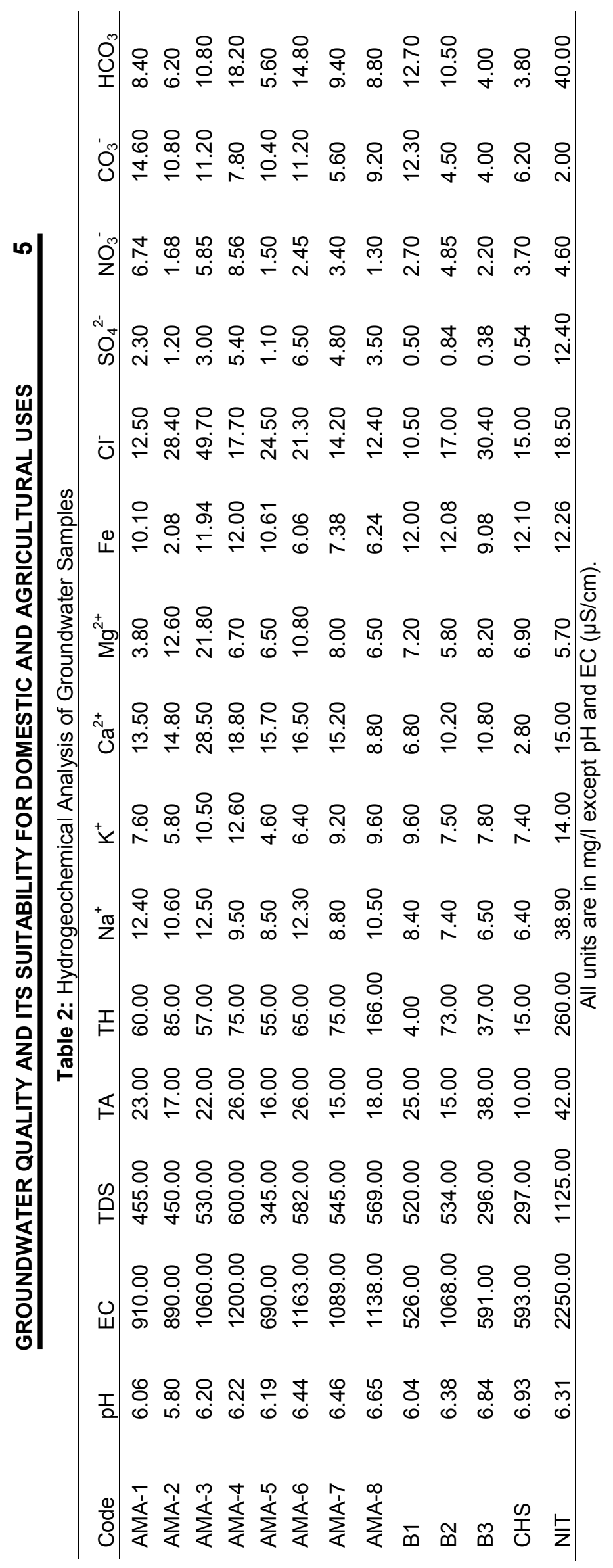


This shows that the groundwater of the study area was weakly acidic. Acidity in groundwater in the Niger Delta has been attributed partly to gas flaring (Nwankwola and Udom 2011). Gas flaring releases carbon dioxide which reacts with atmospheric precipitation to form carbonic acid, which infiltrates into the groundwater system, reduce the $\mathrm{pH}$ of the water, and increase acidity.
Davidson (1995) attributed mild acidity in groundwater to organic acids resulting from decomposition of vegetation in swampy environments and further suggested that this was natural acidification process through $\mathrm{CO}_{2}$ production and root respiration in the soil in such environments.

Table 3: Descriptive Statistics of Analysed Groundwater Samples Compared with Standards

\begin{tabular}{|c|c|c|c|c|c|c|}
\hline Parameter & No of Samples & Minimum & Maximum & Mean & $\begin{array}{l}\text { Standard } \\
\text { Deviation }\end{array}$ & $\begin{array}{l}\text { WHO, } 2004 \\
\text { permissible Limit }\end{array}$ \\
\hline $\mathrm{pH}$ & 13 & 5.8 & 6.84 & 6.4 & 0.32 & $6.5-9.5$ \\
\hline $\mathrm{EC}(\mu \mathrm{S} / \mathrm{cm})$ & 13 & 526 & 1200 & 1012.9 & 441.2 & 1500 \\
\hline TDS (mg/L) & 13 & 296 & 1125 & 526.7 & 207.9 & 1000 \\
\hline $\mathrm{TA}(\mathrm{mg} / \mathrm{L})$ & 13 & 10 & 42 & 22.5 & 9.2 & \\
\hline $\mathrm{TH}(\mathrm{mg} / \mathrm{L})$ & 13 & 4 & 260 & 79 & 66.8 & 500 \\
\hline $\mathrm{Na}^{+}(\mathrm{mg} / \mathrm{L})$ & 13 & 6.4 & 38.9 & 11.8 & 8.4 & 200 \\
\hline $\mathrm{K}^{+}(\mathrm{mg} / \mathrm{L})$ & 13 & 4.6 & 14 & 8.7 & 2.6 & 200 \\
\hline $\mathrm{Ca}^{2+}(\mathrm{mg} / \mathrm{L})$ & 13 & 2.8 & 28.5 & 13.7 & 6.3 & 200 \\
\hline $\mathrm{Mg}^{2+}(\mathrm{mg} / \mathrm{L})$ & 13 & 3.8 & 21.8 & 8.5 & 4.6 & 150 \\
\hline $\mathrm{Fe}(\mathrm{mg} / \mathrm{L})$ & 13 & 2.08 & 12.3 & 9.5 & 3.2 & 0.3 \\
\hline $\mathrm{Cl}^{-}(\mathrm{mg} / \mathrm{L})$ & 13 & 12.5 & 49.7 & 20.9 & 10.6 & 250 \\
\hline $\mathrm{SO}_{4}{ }^{2-}(\mathrm{mg} / \mathrm{L})$ & 13 & 0.38 & 12.4 & 3.3 & 3.4 & 250 \\
\hline $\mathrm{NO}_{3}^{-}(\mathrm{mg} / \mathrm{L})$ & 13 & 1.3 & 8.6 & 3.8 & 2.2 & 50 \\
\hline $\mathrm{CO}_{3}^{-}(\mathrm{mg} / \mathrm{L})$ & 13 & 2 & 14.6 & 8.5 & 3.7 & - \\
\hline $\mathrm{HCO}_{3}^{-}(\mathrm{mg} / \mathrm{L})$ & 13 & 3.8 & 40 & 11.8 & 9.4 & 240 \\
\hline
\end{tabular}

Units in $\mathrm{mg} / \mathrm{L}$ except $\mathrm{pH}$ and $\mathrm{EC}(\mu \mathrm{S} / \mathrm{cm})$. EC: electrical conductivity, TDS: total dissolved solids, TH: total hardness, TA: total alkalinity

Compositional relations in the groundwater are shown in the Pearson correlation matrix (Table 4). 


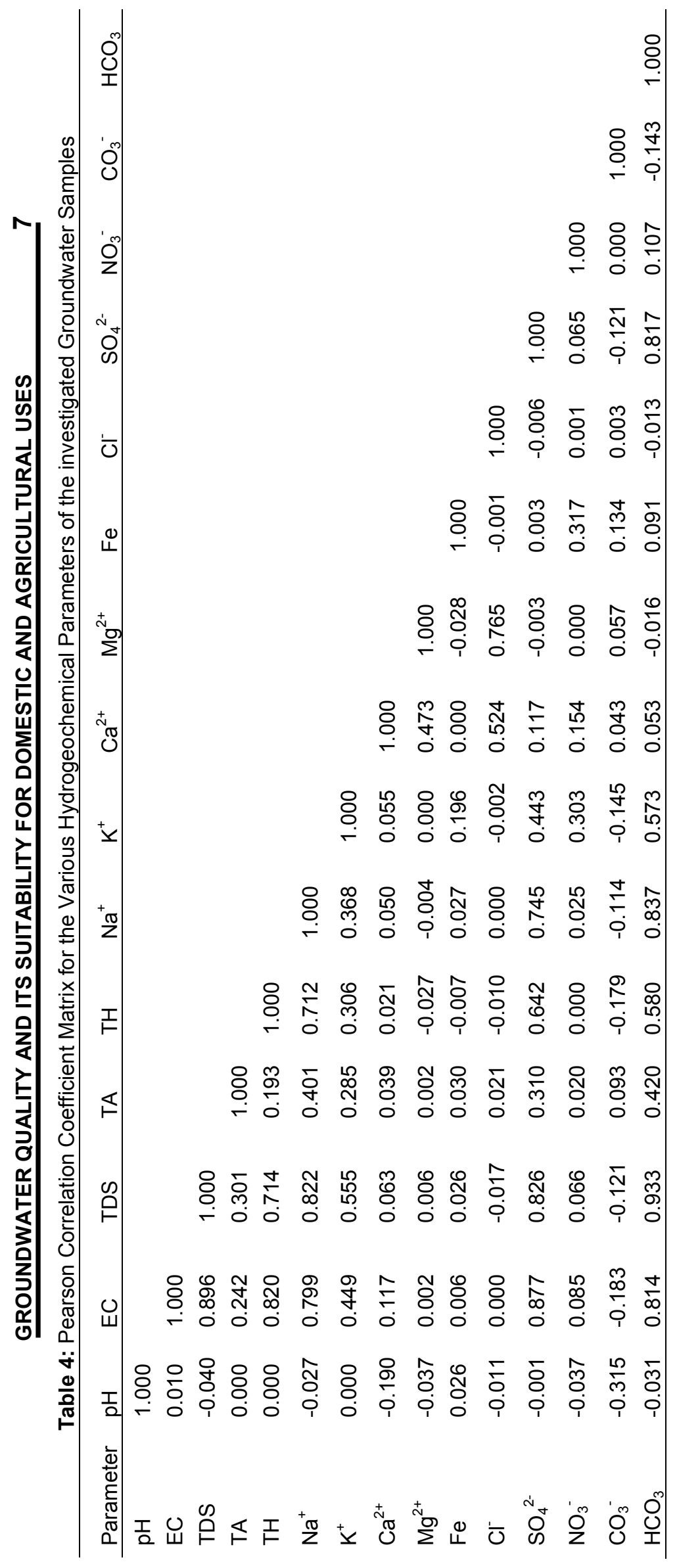


Table 4 shows that the TDS has a strong positive correlation $(r=0.82-0.93)$ with $\mathrm{Na}^{+}, \mathrm{SO}_{4}{ }^{2-}$ and $\mathrm{HCO}_{3}{ }^{-}$ions, and a moderate positive correlation $(r=$ 0.56 ) with $\mathrm{K}^{+}$(Table 4), suggesting that the aquifer chemistry (TDS) to be mainly controlled by $\mathrm{Na}^{+}, \mathrm{SO}_{4}{ }^{2-}$, $\mathrm{HCO}_{3}{ }^{-}$and $\mathrm{K}^{+}$ions. The dissolved ions, such as $\mathrm{Na}^{+}$, $\mathrm{SO}_{4}{ }^{2-}$, and $\mathrm{HCO}_{3}^{-}$show a positive intercorrelation $(\mathrm{r}=$ $0.75-0.84), \mathrm{Mg}^{2+}(r=0.77)$ with $\mathrm{Cl}^{-}$ion, $\mathrm{SO}_{4}{ }^{2-}(r=0.82)$ with $\mathrm{HCO}_{3}{ }^{-}$ions. EC shows a strong correlation $(r=0.80$
- 0.88) with $\mathrm{TH}, \mathrm{Na}^{+}, \mathrm{SO}_{4}{ }^{2-}$ and $\mathrm{HCO}_{3}{ }^{-}$parameters; $\mathrm{TH}$ show moderate correlation $(r=0.58-0.71)$ with $\mathrm{Na}^{+}$, $\mathrm{SO}_{4}{ }^{2-}$ and $\mathrm{HCO}_{3}{ }^{-}$ions.

The obtained matrix of hydrogeochemical data was also subjected to multivariate analytical technique. The Principal Component Analysis (PCA) technique was used in displaying the complex relationships among the variables

(Table

$5)$.

Table 5: Rotated Component Matrix of Chemical Data of Groundwater Samples

\begin{tabular}{|c|c|c|c|c|c|}
\hline \multirow[b]{2}{*}{ Chemical Variables } & \multicolumn{4}{|c|}{ Principal Components } & \multirow[t]{2}{*}{ Communality } \\
\hline & 1 & II & III & IV & \\
\hline $\mathrm{pH}$ & -0.095 & -0.530 & 0.163 & 0.729 & 0.848 \\
\hline EC & 0.957 & 0.030 & -0.154 & -0.003 & 0.940 \\
\hline TDS & 0.965 & -0.010 & -0.115 & -0.128 & 0.961 \\
\hline TA & 0.659 & 0.043 & 0.035 & 0.201 & 0.478 \\
\hline $\mathrm{TH}$ & 0.848 & -0.121 & -0.377 & 0.045 & 0.878 \\
\hline $\mathrm{Na}^{+}$ & 0.927 & 0.011 & -0.176 & -0.024 & 0.891 \\
\hline $\mathrm{K}^{+}$ & 0.800 & 0.007 & 0.383 & 0.029 & 0.789 \\
\hline $\mathrm{Ca}^{2+}$ & 0.303 & 0.889 & 0.065 & 0.020 & 0.887 \\
\hline $\mathrm{Mg}^{2+}$ & -0.086 & 0.875 & -0.051 & 0.341 & 0.891 \\
\hline $\mathrm{Fe}$ & 0.248 & -0.135 & 0.858 & 0.026 & 0.816 \\
\hline $\mathrm{Cl}^{-}$ & 0.042 & 0.840 & 0.027 & 0.494 & 0.953 \\
\hline $\mathrm{SO}_{4}{ }^{2-}$ & 0.932 & 0.016 & -0.152 & -0.012 & 0.892 \\
\hline $\mathrm{NO}^{3-}$ & 0.354 & 0.227 & 0.755 & -0.300 & 0.837 \\
\hline co3- & -0.445 & 0.443 & -0.106 & -0.636 & 0.810 \\
\hline $\mathrm{HCO}_{3}^{-}$ & 0.970 & -0.035 & 0.019 & -0.106 & 0.954 \\
\hline Eigenvalues & 6.803 & 2.827 & 1.733 & 1.460 & \\
\hline \multicolumn{6}{|l|}{$\%$ of variance explained } \\
\hline by component & 45.355 & 18.85 & 11.556 & 9.731 & \\
\hline Cumulative $\%$ variance & 45.355 & 64.205 & 75.761 & 85.492 & \\
\hline
\end{tabular}

Table 5 shows that factor 1 accounts $45.36 \%$ variance in the data. The variables present in this factor are $\mathrm{Na}^{+}, \mathrm{K}^{+}$, and $\mathrm{SO}_{4}{ }^{2-}$ and $\mathrm{HCO}_{3}^{-}$which indicates ion exchange and weathering of basic materials of soil. The combinations $\mathrm{Na}^{+}, \mathrm{K}^{+}$, and $\mathrm{SO}_{4}{ }^{2-}$ and $\mathrm{HCO}_{3}{ }^{-}$ions, influencing the high positive loadings observed on the first principal component (Table 5), suggest that the first principal component is associated with a combination of various hydrogeochemical processes that contribute to enrich more mineralized water (TDS). Factor 2 accounts for $18.85 \%$ of total variance, with the high loadings for $\mathrm{Ca}^{2+}, \mathrm{Mg}^{2+}$ and $\mathrm{Cl}^{-}$attributed to the silicate weathering processes and reverse ion exchange. Factor 3 accounts $11.56 \%$ variance in the data with variables like $\mathrm{Fe}$ and $\mathrm{NO}_{3}{ }^{-}$. Factor 4 accounts for $9.73 \%$ of variance in the data. This factor show high positive loadings only for $\mathrm{pH}$.

The TDS, which is a measure of the degree of quality, is in the range of $296-1125 \mathrm{mg} / \mathrm{L}$, with a mean of $526.7 \mathrm{mg} / \mathrm{L}$. Based on the classification of TDS (Fetter 1990), all the groundwater samples belong to the freshwater category (TDS $<1000 \mathrm{mg} / \mathrm{L}$ ) except sample 13 which could be classified as brackish water (TDS > $1500 \mathrm{mg} / \mathrm{L}$ 
Table 6: Quality of Irrigation Water Based on Electrical Conductivity

\begin{tabular}{llll}
\hline EC $(\mu \mathrm{s} / \mathrm{cm})$ & Water class & Wells & Total no of wells \\
\hline$<250$ & Excellent & Nil & 0 \\
$250-750$ & Good & $5,9,11,12$ & 4 \\
$750-2000$ & Permissible & $1,2,3,4,6,7,8,10$ & 8 \\
$2000-3000$ & Doubtful & 13 & 1 \\
$>3000$ & Unsuitable & Nil & 0 \\
\hline
\end{tabular}

The $\mathrm{TH}$ in the groundwater is in the range of $4.0-$ 260mg/L (Table 7), and indicates that samples 1, 3, 5, 6, $9,10,11$ and 12 could be classified as soft water $(\mathrm{TH}<$
$75 \mathrm{mg} / \mathrm{L}$ ), samples 2,4 and 7 are moderately hard (TH range between $75-150 \mathrm{mg} / \mathrm{L}$ ) while 8 and 13 are hard ( $\mathrm{TH}$ range between $150-300 \mathrm{mg} / \mathrm{L}$ ).

Table 7: Alkalinity Hazard Classes of Groundwater

\begin{tabular}{lllll}
\hline SAR & Alkalinity hazard & Water class & Wells & Total no of wells \\
\hline$<10$ & S1 & Excellent & Nil & 0 \\
$10-18$ & S2 & Good & $2,5,7,8,10,12$ & 6 \\
$18-26$ & S3 & Doubtful & $1,3,4,6,9$, & 5 \\
$>26$ & S4 & Unsuitable & 11,13 & 2 \\
\hline
\end{tabular}

The concentrations of sodium in the samples ranged from $6.4-38.9 \mathrm{mg} / \mathrm{L}$ with a mean of $11.8 \mathrm{mg} / \mathrm{L}$. The recommended limit for sodium concentration in drinking water is $200 \mathrm{mg} / \mathrm{L}$. A higher sodium intake may cause hypertension, congenial heart diseases and kidney problems (Singh et al. 2008). The concentrations of sodium are below the prescribed limit of $200 \mathrm{mg} / \mathrm{L}$. Potassium concentration ranged from $4.6-14 \mathrm{mg} / \mathrm{L}$ with a mean of $8.7 \mathrm{mg} / \mathrm{L}$, i.e below the $\mathrm{WHO}$ recommended limit of potassium concentration in drinking water. Calcium concentration ranged from $2.8-28.5 \mathrm{mg} / \mathrm{L}$ with a mean of $13.7 \mathrm{mg} / \mathrm{L}$. Magnesium concentration ranged from $3.8-21.8 \mathrm{mg} / \mathrm{L}$ with a mean of $8.5 \mathrm{mg} / \mathrm{L}$. Sodium, calcium and magnesium are species that can be derived from the chemical weathering of feldspars and micas. The sedimentary rocks in the study area contain unconsolidated alluvial deposits with mixed assemblages of minerals derived from sedimentary, igneous and metamorphic sources. As a result, fine fragments of feldspars occur with terrigeneous alternations of sands, clays and shales. All three ions, $\mathrm{Na}^{+}, \mathrm{Ca}^{2+}$, and $\mathrm{Mg}^{2+}$ are among the species that are constantly involved in cation exchange processes and interaction with aquifer material (Mercado 1985).

The concentration of iron ranged from 2.08 $12.3 \mathrm{mg} / \mathrm{L}$ with a mean of $9.5 \mathrm{mg} / \mathrm{L}$. Table 2 shows that the concentration of iron in all samples is over $3000 \%$ higher than the safe limit of $0.3 \mathrm{mg} / \mathrm{L}$ stipulated by $\mathrm{WHO}$ for drinking water. The concentration of iron had been noted to be generally high in the study area (Amadi et al. 1987). Most of the waters are clear when first drawn from the well but soon become cloudy and then brown from precipitating ferric hydroxide. Though conclusive evidence is lacking as to the exact source of this high iron activity, Amadi et al. (1987) suggested that important factors that influence iron solubility and subsequently its concentration in groundwater include the local geologic structure, hydrological conditions of the basin, and complex physicochemical and biochemical factors such as the $\mathrm{pH}$ and redox potential (Eh), dissolved carbon dioxide and sulphur species, organic substances with high capacity to form complexes including humic substances, and the content and composition of microflora.

The unconsolidated alluvial deposits also contain mixed assemblages of pyroxene, amphibioles, biotite, magnetite, and olivine, and these are iron bearing minerals which can be derived from sedimentary, igneous and metamorphic sources (Amadi et al. 1987). Additionally, shales, which are common in the study area, are known to contain high amounts of iron (Amajor 1991). The leaching of the Niger Delta shales is a possible source for the iron contamination. Furthermore, the fact that the groundwater occurs at shallow depths (less than $20 \mathrm{~m}$ ) suggests an open system where there is frequent contact between such waters and the atmosphere. Recharge reaching the water table is generally oxygenated owing to this contact and any reduced iron minerals especially pyrite, which the solution comes in contact will be attacked to yield ferric iron and sulphate. Hem (1970) has attributed high iron contents in groundwater to the oxidation of reduced iron in sedimentary materials.

Chloride concentrations in the samples were from 12.5 to $49.7 \mathrm{mg} / \mathrm{L}$ with a mean value of $20 \mathrm{mg} / \mathrm{L}$, i.e is below the WHO permissible limit of $200 \mathrm{mg} / \mathrm{L}$. Sulphate concentrations in these groundwater samples ranged from 0.38 to $12.4 \mathrm{mg} / \mathrm{L}$ i.e below the maximum allowable limit, therefore possed no groundwater problem. Nitrate concentrations ranged from 1.3 to 8.6 $\mathrm{mg} / \mathrm{L}$ with a mean value of $3.8 \mathrm{mg} / \mathrm{L}$. The nitrate concentrations in the samples were below allowable limit of $45 \mathrm{mg} / \mathrm{L}$. The bicarbonate anion concentrations were in the range of $3.8-40 \mathrm{mg} / \mathrm{L}$ with a mean value of 11.8 $\mathrm{mg} / \mathrm{L}$. The carbonate concentrations ranged from $2.0-$ $14.6 \mathrm{mg} / \mathrm{L}$ with a mean of $8.5 \mathrm{mg} / \mathrm{L}$.

The composition of waters reflects the effects of chemical processes occurring between the minerals 
within the lithologic framework and the flowing groundwater. One useful method of analysis of the response of waters in such a system is the evaluation of the prevalent chemical character of the waters as related to the lithologic pattern. By determining the dominant cation and anion, expressed in milliequivalent per litre and plotting on a Piper trilinear diagram, the water can be classified by its chemical character. Details regarding the geochemical interpretation of the water samples can be found in Piper (1953) and Hem (1985). In the cation plot field (Fig. 2), the samples cluster mainly in the no dominate type field. In the anion plot, the samples mostly cluster in the bicarbonate and chloride facie indicating bicarbonate and chloride type water. The ground water is generally of $\mathrm{Ca}-\mathrm{HCO}_{3}$ and $\mathrm{Ca}-\mathrm{Cl}-\mathrm{HCO}_{3}$ types based on the Piper (1944) plot (Fig. 2). The assemblage of groundwater types in the area shows that both compound and single groundwater types occur. $\mathrm{Ca}-\mathrm{HCO}_{3}$ type of water is likely caused by rainfall recharge processes, associated with low EC values (Lakshmanan et al. 2003). The alkali earths metals $\left(\mathrm{Ca}^{2+}\right.$ and $\left.\mathrm{Mg}^{2+}\right)$ and strong acids $\left(\mathrm{Cl}^{-}\right.$and $\left.\mathrm{SO}_{4}{ }^{2-}\right)$ are slightly dominating over the alkali metals $\left(\mathrm{Na}^{+}\right.$and $\left.\mathrm{K}^{+}\right)$and weak acid anions $\left(\mathrm{HCO}_{3}{ }^{-}\right.$and $\left.\mathrm{CO}_{3}{ }^{2-}\right)$ type of water (Fig. 2).

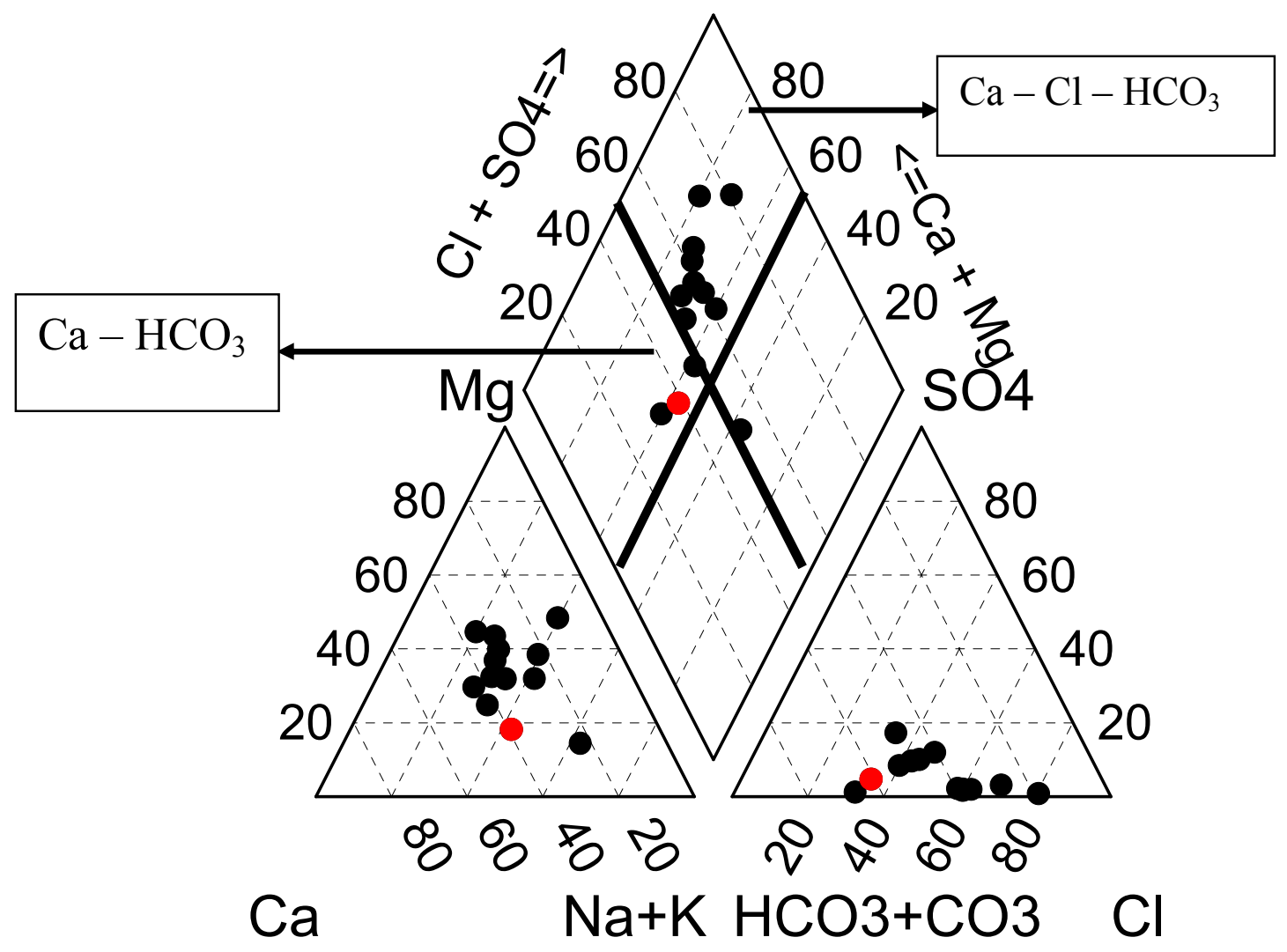

Fig.2: Chemical Facies of Groundwater in Piper Diagram

The water quality evaluation in the area of study was also carried out to determine its suitability for agricultural purposes. The suitability of groundwater for irrigation is contingent on the effects on the mineral constituents of the water on both plants and the soil. In fact, salts can be highly harmful. They can limit growth of plants physically, by restricting the taking up of water through modification of osmotic processes. Also salts may damage plant growth chemically by the effects of toxic substances upon metabolic purposes. Parameters such as EC (Table 6), percent sodium, and sodium adsorption ratio (SAR) were used to assess the suitability of water for irrigation purposes. Electrical conductivity (Table 6) is a good measure of the salinity hazard to crops as it reflects the TDS in groundwater. Based on the US salinity diagram (Fig. 3), about $69 \%$ of the samples fall in the high salinity hazard class (C3) and may have detrimental effects on sensitive crops and adverse effects on many plants as excess salinity reduces osmotic activity of plants and thus interfere with the absorption of water and nutrients from the soil (Saleh et al.

1999). 


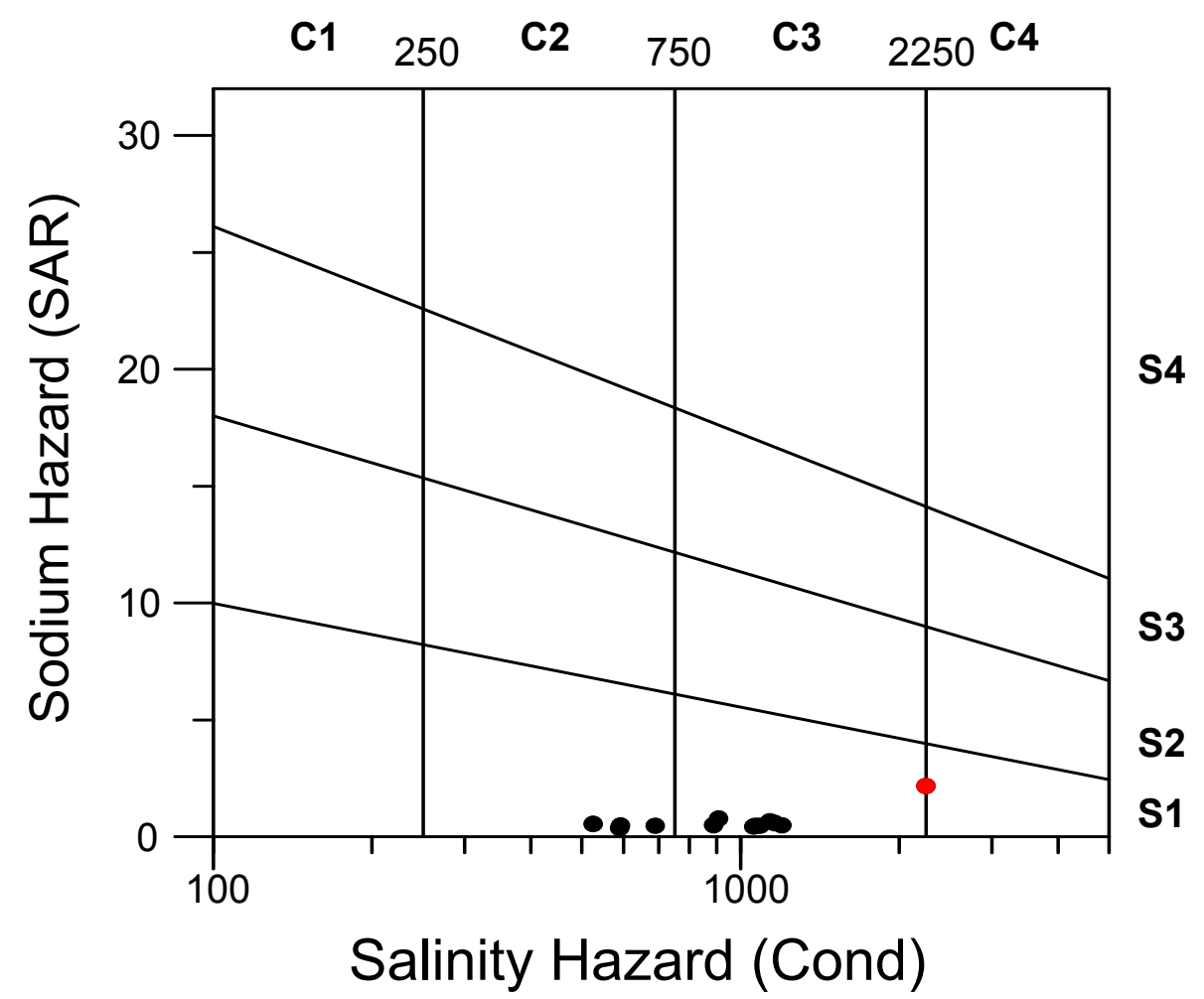

Fig.3. Wilcox Diagram presenting the sodium/salinity hazard of the groundwater in Wilberforce Isand

The Wilberforce Island area thus requires careful management practices. Sodium adsorption ratio (SAR) is an important parameter for determining the suitability of groundwater for irrigation because it is a measure of akali/sodium hazard to crops. SAR was calculated using the following formula:
$\mathrm{SAR}=\frac{\mathrm{Na}^{+}}{\left[\mathrm{Ca}^{2+}+\mathrm{Mg}^{2+}\right]^{1 / 2} / 2}$

where the concentrations are reported in meq/L. The SAR values range from $0.64-3.07$ with an average $\begin{array}{lll}\text { value of } & 0.90 \quad \text { (Table }\end{array}$ 8).

Table 8: Suitability of Groundwater for Irrigation Based on Percent Sodium

\begin{tabular}{llll}
\hline$\% \mathrm{Na}$ & Water class & Wells & Total no of wells \\
\hline$<20$ & Excellent & Nil & 0 \\
$20-40$ & Good & $2,3,4,5,6,7,9,10,11,12$ & 10 \\
$40-60$ & Permissible & $1,8,13$ & 3 \\
$60-80$ & Doubtful & Nil & 0 \\
$>80$ & Unsuitable & Nil & 0 \\
\hline
\end{tabular}

Groundwater samples of the study area fall in low sodium class (S1) (Fig.3). This implies that no alkali hazard is anticipated for the crops irrigated with the water samples. High SAR value $(>6-9)$ leads to a break down in the physical structure of the soil caused by excessive amounts of colloidally absorbed sodium. This breakdown results in the dispersion of soil clay that causes the soil to hard compact when dry and increasingly impervious to water penetration due to dispersion and swelling when wet. Fine - textured soils, those high in clay, are especially subject to this action (Saleh et al. 1999).
The sodium percentage ( $\mathrm{Na} \%)$ was calculated using the formula:

$$
\mathrm{Na}(\%)=\frac{\left(\mathrm{Na}^{+}+\mathrm{K}^{+}\right) \times 100}{\left(\mathrm{Ca}^{2+}+\mathrm{Mg}^{2+}+\mathrm{Na}^{+}+\mathrm{K}^{+}\right)},
$$

where all concentrations are expressed in meq/l.

The values for $\mathrm{Na} \%$ in the study area range from 20 to $63 \%$. It was observed that $\mathrm{Na} \%$ in the groundwater is good to permissible for irrigation except sample 13 falling in the field for doubtful. On the Wilcox (1955) diagram relating sodium percentage and total concentration, most of the groundwater samples fall 
within the field of good to permissible conditions for irrigation (Fig. 3). When the concentration of sodium is high in irrigation water, sodium ions tend to be absorbed by clay particles, displacing $\mathrm{Mg}^{2+}$ and $\mathrm{Ca}^{2+}$ ions. This exchange process of $\mathrm{Na}^{+}$in water for $\mathrm{Ca}^{2+}$ and $\mathrm{Mg}^{2+}$ in soil reduces the permeability and eventually results in soil with poor internal drainage. Hence, air and water circulation is restricted during wet conditions while such soils are usually hard when dry (Collins and Jenkins 1996; Saleh et al. 1999).

\section{CONCLUSION}

Interpretation of hydrogeochemical analysis of groundwater samples collected from domestic boreholes in parts of the Wilberforce Island, Bayelsa showed that the groundwater is slightly acidic on account of the $\mathrm{pH}$ values which range from $6.04-6.93$ and fresh in nature. The sequence of abundance of major ions is in the following order: $\mathrm{Ca}^{2+}>\mathrm{Na}^{+}>\mathrm{K}^{+}>\mathrm{Fe}>\mathrm{Mg}^{2+}$ and $\mathrm{Cl}^{-}>$ $\mathrm{HCO}_{3}^{-}>\mathrm{CO}_{3}^{-}>\mathrm{NO}_{3}^{-}>\mathrm{SO}_{4}^{2-}$ for cations and anions respectively. The concentration of these ions as well as parameters such as total hardness and TDS are below the World Health Organisation (WHO) standard for drinking water in over $80 \%$ of the samples. The alkali earths metals $\left(\mathrm{Ca}^{2+}\right.$ and $\left.\mathrm{Mg}^{2+}\right)$ and strong acids $\left(\mathrm{Cl}^{-}\right.$and $\left.\mathrm{SO}_{4}{ }^{2-}\right)$ are slightly dominating over the alkali metals $\left(\mathrm{Na}^{+}\right.$ and $\left.\mathrm{K}^{+}\right)$and weak acid anions $\left(\mathrm{HCO}_{3}{ }^{-}\right.$and $\left.\mathrm{CO}_{3}{ }^{2-}\right)$ type of water. The assemblage of groundwater types in the area shows that both compound and single groundwater types occur but generally of $\mathrm{Ca}-\mathrm{HCO}_{3}$ and $\mathrm{Ca}-\mathrm{Cl}-$ $\mathrm{HCO}_{3}$ types.

\section{ACKNOWLEDGEMENTS}

The authors are grateful to the post-graduate geophysics students in the Department of Geology and Physics who assisted in the collection of samples and $\mathrm{Mr}$ Suoye Diete-Spiff of the Central Research Laboratory, Niger Delta University for the physicochemical analysis of the samples.

\section{REFERENCES}

Allen, J. R. L., 1965. Late Quaternary Niger Delta and adjacent areas: sedimentary environments and lithofacies. American Association of petroleum Geologists Bulletin, (49): 549 - 600 .

Amadi, P. A., Ofoegbu, C. O and Morrison, T., 1987. Hydrogeochemical assessment of groundwater quality in parts of the Niger Delta, Nigeria. Environmental Geology and Water Science. 14, 195-202.

Amajor, L. C., 1991. Aquifers in the Benin Formation (Miocene - Recent), Eastern Niger Delta, Nigeria. Lithostratigraphy, Hydraulics and water quality. Environmental Geology \& Water Science, 17, (2): $85-101$.

Andre, L., Franceschi, M., Pouchan, P and Attesia, O., 2005. Using geochemical data and modelling to enhance the understanding of groundwater flow in a regional deep aquifer, Aquitaine Basin, south-west of France. Journal of Hydrology, $305,40-62$.

APHA., 1998. Standard methods for the examination of water and wastewater, $19^{\text {th }}$ edition, American Public Health Association, Washington DC, USASS.

Collins, R and Jenkins, A., 1996. The impact of agricultural land use on stream chemistry in the middle hills of the Himalayas, Nepal. Journal of Hydrology, 185, 71-86.

Davidson, W. A., 1995. Hydrogeology and groundwater resources of the Perth Region, Western Australia. Geological Survey of Western Australia, Government of Western Australia, Perth. Bulletin. 142, 257-259.

Fetter, R. S., 1990. Applied hydrogeology: New Delhi, India, CBS Publishers and distributors, 592p.

Durotoye, B., 1989. Quaternary sediments in Nigeria: In C.A. Kogbe (Ed.), Geology of Nigeria, Rock View (Nigeria) Ltd. Publishers, Jos,

Hem, J. D., 1985. Study and interpretation of chemical characteristics of natural water, US Geological Survey, Water Supply Paper No 2254.

Hem, J. D., 1970. Study and interpretation of chemical characteristics of natural water, US Geological Survey, Water Supply Paper No 1473.

Kogbe, C. A., 1989. The Cretaceous and Paleogene sediments of southern Nigeria. In: C.A. Kogbe, (Ed.), Geology of Nigeria, (pp. 311-334), Elizabethan Press, Lagos.

Lakshmanan, E., Kannan, K and Senthil Kumar, M., 2003. Major ion chemistry and identification of hydrogeochemical process of groundwater in part of Kancheepuram district, Tamilnadu, India. Journal of Environmental Geosciences, 10 (4): $157-166$.

Merccado, A., 1985. The use of hydrogeochemical patterns in carbonate, sand and sandstone aquifers to identify intrusion and flushing of saline water. Groundwater, 23, 635 - 645.

Nwankwola, H. O and Udom, G. J., 2011. Hydrogeochemical evaluation of groundwater in parts of Eastern Niger Delta, Nigeria. Journal of Academic and Applied Studies. 1, 33-58.

Oomkens, E., 1974. Lithofacies relations in the Late Quaternary Niger Delta complex. Sedimentology, 21, $195-222$.

Osakuni, M. U and Abam, T. K. S., 2004. Shallow resistivity measurement for cathodic protection of pipelines in the Niger Delta. Environmental Geology. 45, 747-752. 
Piper, A. M., 1944. A graphical interpretation of water Analysis: Transactions of the American Geophysical Union, 25, 914 - 928.

Piper, A. M., 1953. A graphic procedure in the geochemical interpretation of water analysis, USGS groundwater note no.12.

Prasanna, M. V., Chidambaram, .S., Shahul A. H and

Srinivasamoorthy, K., 2011, Hydrogeochemical analysis and evaluation of groundwater quality in the Gadilam river basin, Tamil Nadu, India. Journal of Earth system science, 120, 85 - 98.

Saleh, A., Al-Ruwath, F and Shehata, M., 1999. Hydrogeochemical processes operating within the main aquifers of Kuwait. J. Arid Environ. 42, 195-209.

Singh, V and Singh, U. C., 2008. Assessment of groundwater quality of parts of Gwalior (India) for agricultural purposes. Indian Journal of Science and Technology. 1, 1-5.

World Health Organisation (WHO)., 2004. Guidelines for drinking water quality: incorporating $1^{\text {st }}$ and $2^{\text {nd }}$ vol. 1 recommendations $3^{\text {rd }}$ ed., Geneva.

Wright, J. B., Hasting, D. A., Jones, W. B and Williams, H. R., 1985. Geology and mineral resources of West Africa, Allen and Unwin Limited, UK, 107pp.

Short, K. C and Stauble, A. J., 1967. Outline of the geology of the Niger Delta. Bull. AAPG. 51,761779 . 